\title{
Den moderne Sovjetlitteratur
}

Historien har vist, at dynamiske processer af den art sovjetsamfundet gennemgår i øjeblikkket normalt sætter spor i kunsten. »Pcrestrojkaen«, som Gorbatjov og mange andre endda kalder en revolution, har nu varet i mere end fire år. Man kunne således forvente, at der i løbet af denne periode var »sket noget « i litteraturen. Det er der også. Men ikke i selve den litterære process. Derimod er der sket cn del i det litterare liv. Det, vi har at gøre med, er en ny litterær situation.

Den litteratur, der hidtil har domineret, og som har vakt mest opmærksomhed under »perestrojka«, er »gammck værker, der er skrevet i Brezjhnev-tiden, men også så langt tilbage som i 20'erne og 30'erne, ja, endda før revolutionen. Det er værker, der tidligere har varet forbudt, eller som er udkommet en gang for længe siden, men ikke blevet genoptrykt, og det er varker, der har været publiceret, men i stærkt censurerede udgaver.

Den »ny« sovjetlitteratur er således skrevet i en tidligere litterær og historisk kontekst. Dermed er den, set ud fra et litteraturhistorisk synspunkt, ikke moderne, fordi den ikke cr samtidig. Noget andet er så, at den kan skrive sig ind $i$ en modernitetstradition, passes ind under forskellige modernitetsopfattelser osv. Men det er en anden diskussion.

Receptionsteoretisk er det også et interessant problem. For det cr klart, at den sovjetiske læser jo opfatter disse nu frigivne værker som "gamle«. Mcn samtidig opleves de nctop også som samtidige i betydningen mulige at læse nu. Det er altså ikke det samme som at læse en gammel klassiker, som man kunne have læst på et hvilket som helst andet tidspunkt, men bare ikke har fået gjort. Det drejer sig om værker, som den aktuelle situation har gjort det muligt at læse. Lasningen af tidligere forbudte værker (eller »glemte« som det hedder officielt) er ofte, har jeg fået fortalt, en stæerk kollektiv oplevelse. Den enkelte laser ved, at der samtidig med ham eller hende sidder $i$ tusindvis af andre og laeser det samme "glemte værk. Den forsvundne fortid, den fortrangte historiske crindring vender tilbage i en særegen, punktvis koordineret kronologi. 
I stedet for moderne er det således mere rimeligt at tale om 'den aktuelle' sovjetlitteratur. Det mest interessante og helt specielle ved den er netop dens forskudte og »fremmede « udtryksform. Vi har at gøre med en samtid, der ikke har fundet sit adækvate litterære sprog. Sovjetsamfundet er, for at sige det metaforisk og med en lånt formulering fra en af emigrantforfatteren Vasilij Aksjonovs romantitler På jagt efter en genre (1978, på dansk 1981).

Selvfølgelig bliver der også udgivet nye littcrære værker. Men det er ikke dem, der dominerer, og jeg mener ikke, at der er grund til at tale om ny, original litteratur. Som eksempel på nyskrevne værker, der har vakt kritikkens opmærksomhed, kan nævnes Michail Kurajevs tilsyneladende fantastiske men i virkeligheden realistisk-præcise roman om Kronstadtoprøret i 1921, Kaptajn Dickstein (1987) og Tatjana Tolstajas Tjekhovinspirerede novelle-samling $P \stackrel{\circ}{\text { en }}$ guldveranda (1987, flere af novellerne er dog skrevet i tiden før perestrojka). Flere af de store såkaldte 'glasnostværker', f.eks. Anatolij Rybakovs historisk-psykologiske roman om Sovjet i 30'erne, Børn af Arbat (1987, på dansk 1988), Daniel Granins Uroksen (1987), der handler om sovjetiske videnskabsmænds skæbne i stalintiden, og Vladimir Dudintsevs Hvide klader (1987) over det samme tema, men med fokus også på Chrustjov-tiden, er allesammen skrevet og refuseret $\mathrm{i}$ Brezjnev-tiden. De ligger i forlængelse af »opgørs-litteraturen« fra det første »tøbrud«, der blev afbrudt i midten af $60^{\prime}$ erne. I virkeligheden er disse romaner 50'er-generationens forsinkede, men til gengæld forstærkede »dom« over stalintiden. Til denne gruppe hører også Andrej Bitovs Pusjkin-huset, der udkom på russisk i USA i 1978, men som først blev tilgængelig for sovjetiske læsere i 1987 (dansk 1988). Pusjkin-huset er en poetistisk roman om romankunsten. Den skriver sig ind i en fabulistisk tradition med rødder i 1800-tals klassikerene Nikolaj Gogol og Fjodor Dostojevskij, symbolisten Andrej Belyj og de i Stalin-tiden forkætrede, anti-utopister Michail Bulgakov og Andrej Platonov. Pusjkin-huset's ironisk-eksperimenterende stil rimede dårligt med den officielle norm for hvordan litteratur skulle se ud, den så kaldte socialistiske realisme. Afvigelser fra den litterære norm snarere end et uakceptabelt politisk indhold var også årsagen til at ovennævnte Vasilij Aksjonov 'blev emigreret' i 1982.

Også idag taler man om et »tøbrud«. Man er inde i en opbruds- og overgangsfase. Kreativ skaben kraver overblik og distance. Forfatterne (ligesom sovjetborgerne i øvrigt) befinder sig i en situation, hvor All flyder (1953-64) der er titlen på en tidligere forbudt roman om stalintiden, skrevet af Vasilij Grossman og nu under udgivelse på et af de store 
litterære tidsskrifter. Det ser ud, som om forfatterne er optaget af at finde ud af, hvordan virkeligheden ser ud, inden de kan gå i gang med at beskrive den. Man foretrækker at investere sin energi i den offentlige debat frem for at skrive »for evigheden «.

Journalistisk publicistik, debatartikler og konferenceindlæg cr blevet perestrojkaens genre nummer et. To af periodens vigtigste nyskabelser, som også er udkommet på dansk, er udmærkede eksempler på, at også det, der er udgivet som fiktion, bærer tydeligt præg af journalistik og debatindlæg. Viktor Astafjevs Den sørgmodige detektiv, der udkom i 1986 (dansk 1987), er udformet som en politibetjents registreren og reflekteren i dagbogsform over sociale misforhold og kriminalitet i sibiriske provinsbyer. Tjingis Ajtmatovs omfangsrige roman Skafottet fra 1986 (dansk 1987) er det andet eksempel. På trods af at en stor del af romanen kredser om evige, universelle, religiøse problemstillinger, er tematikken i høj grad dagsaktuel og tidstypisk. Ligesom Astafjev skriver Ajtmatov om akutte sociale problemer (kriminalitet, narkotikamisbrug, miljøproblemer), og ligesom Astafjev bryder han ind i fiktionen med udførlige kommentarer og ræsonnerende betragtninger henover hovedet på personerne. Det gør også Valentin Rasputin i et tredje og ligeså centralt eksempel på den nye, "publicistiske « litteratur. Det hedder Branden og kom i øvrigt før de to andre, i 1985. Den er endnu ikke oversat til dansk, men den er på vej. (Da Rasputin hørte om det, udtrykte han sin forbløffelse og tvivlede på at den ville interessere danske læsere. - Det er jo vores interne problemer den handler om, sagde han.)

Disse tre værker har spillet en vigtig rolle i den politiske debat. Mange af de problemer, de berører, var tidligere tabuemner og måtte ikke diskuteres offentligt. Ajtmatov, for at tage et eksempel, var den første, der tog narkotikaproblemet op. I kølvandet på Skafottet startede en åben diskussion om emnet i de landsdækkende aviser og tidsskrifter. I »stagnationsperioden « benyttede forfatterne sig af ironiske tvetydigheder, mytologiske overstrukturer og æsopiske omformuleringer for at skjule et kritisk budskab for censuren. I dag ønsker de at sige sandheden uden omsvøb og læserne åbenbart at høre den netop i denne form. Rapporter fra virkelighedens verden, dokumentarisme er »perestrojkaens « kreative udtryksform. Men det er ikke nødvendigvis litteratur.

Hvad angår de tre sidstnæunte forfattere er der også tale om en personlig kreativ krise. I 60'erne og 70'erne skrev de om truede kulturer. Rasputin og Astafjev skildrede den uddøende russiske bondekultur. Ajtmatov, der kommer fra sovjetrepubliken Kirgisien, hentede st of til sine romaner i central-asiatiske folkeslags nationale og åndelige tradition. Flere 
af deres romaner fra denne periode hører til hovedværkerne i moderne sovjetlitteratur. Det gælder f.eks. Astafjevs En sidsta hälsning 1978 (svensk 1981), Rasputins Lev og husk (1974, dansk 1986), Afsked med Matjora (1976, dansk 1986), Ajtmatovs Farvel Gulsary (1966, dansk 1974) og Vigesporet (1980, dansk 1985). I deres seneste værker skildrer de det moderne samfund og det moderne menneskes problemer. Ingen af dem gør det med samme poetiske kraft og analytiske dybde, som da de beskæftigede sig med det traditionelle samfund og 'fortidens' menneske.

Der er imidlertid også andre forklaringer på, at litteraturen er 'gået i stå'. I 70'erne foretrak litterære tidsskrifter og forlag klart etablerede navne. De var også stærkt repræsenteret i de littcrære tidsskrifters redaktioner. Det var ikke nemt for unge, ukendte talenter at gøre sig galdende. Man taler endda om en tabt generation. I dag er det om muligt endnu vanskeligere for unge, ukendte navne at gøre sig gældende. "Alternative« forlag er stadigvæk sjældne, og de har ikke samme spredningskapacitet og gennemslagskraft som de statslige forlag og de centrale, prestigefyldte litterære tidsskrifter. Hvilken forlægger eller redaktør satser på en ukendt debutant, når der ligger upublicerede værker af Boris Pasternak, Anna Achmatova, VI. Nabokov eller Vasilij Grossman i de nyåbnede censurarkiver? Det er ikke bare »døde« store navne, der er rift om. Også de levende store fra tøbruddet og 70'erne har et og andet liggende i 'skrivebordsskuffen'. De unges situation er ikke blevet bedre af, at forlagene og tidsskrifterne er blevet pålagt selv at svare for den $\emptyset$ konomiske balance. Indtil de »forbudte fonde « er udtømt og fortidsboomet er overstået, må den ny litteratur og den unge generation stå i venteposition.

Det er næppe en tilfældighed, at der, hvor de unge kræfter har kunnet gøre sig galdende, er inden for poesien, poesi fylder jo ikke så meget, hvis der er slagsmål om tryksvartcn og spaltepladsen. Poesi er ungdommens og måske også øjeblikkets genre par excellence, og poesien blomstrer gerne i opbrudstider. Årene umiddelbart efter oktoberrevolutionen og 50'ernes tøbrud var poetiske »boom«-perioder. I efteråret 1988 kunne vi her i Danmark opleve en gruppe nye, unge poetiske talenter: Ilja Kutik, Ivan Zjdanov, Aleksej Parstjikov, Marina Kudinora og Oleg Chlebnikov symptomatisk ekskorteret af to af de helt store navne fra 50'erne og 60'erne, Andrej Voznesenskij og Bella Achmadulina. I forbindelse med dette besøg udgav Husets Forlag i Århus en række novelle-samlinger af de gasteoptrædende poeter: Marina Kudinora $I$ pausen i provinsen, Ivan Zjdanov Tavsheds hvide frugt, Aleksej Parsjtjikov Intuitionsfigurer, Oleg Chlcbnikov Lokal tid, Ilja Kutik Sansemes fenkamp, 
Andrej Voznesenskij Jeg brander - altså er jeg, Bella Achmadulina Efterårsuret samt af Bulat Okudzjara, der dog ikke var med i gruppen, men toenk også lidt på mig.

Men tilbage til den gamle, ny litteratur. Generelt kan man sige, at denne litteratur udgør et modbillede til det billede af virkeligheden, mennesket og historien, som magthaverne ønskede og forlangte bekræftet af kunstnerne. I følge den socialistiske realisme skulle forfatterne, der af Stalin blev kaldt »menneskesjælens ingeniører«, efterkomme en af Marx' berømte teser over Feuerbach, hvori det hedder: Filosofferne har kun fortolket verden, hvad det kommer an på er at forandre den. Konkret betød det, at forfatterne ikke skulle beskrive og fortolke virkeligheden som den var, men som den burde være. De skulle gøre det ved hjælp af en positiv helt, hvis væsentligste opgave var at bekrieftede »historiens logik«, det vil sige samfundets lovmæssige udvikling frem imod kommunismen.

I den litteratur, der fulgte dette skema, blev den menneskelige erfaring erstattet med ideologisk bevidsthed, virkelighedsbeskrivelsen blev erstattet med myteproduktion om den 'Fremtidige Harmoni', jeg'et forsvandt i en kollektiv inkarnering af en »højere fornuft«. Eksistentielle og etiske problemer blev overflødige, eftersom »det nye menneske« under socialismen erkender den »historiske nødvendighed« og styrer sit følelsesliv og sin sociale adfærd efter denne erkendelse. Selv om den legale litteratur forlængst havde forladt den socialistiske realismes primitive forskrifter, kom det som et chok for sovjetiske læsere, at litteratur kunne se ud og indeholde det, der stod at læse $i$ en række lavmælte, stilfærdigt sammenflettede digte, publiceret under titlen Requiem (1987) og skrevet af digterinden Anna Achmatova. Requiem handler om stalintidens terror, om skrækken og den dybe angst i menneskenes øjne, om enkeltindividets magtesløshed over for det væeldige maskineri, der i historiens og fremtidsparadisets navn tilintetgør og $\emptyset$ delægger millioner af menneskers liv.

Requiem er et mægtigt opgør med stalintiden og den primitive myte om »historiens fornuft «. Digtene stammer fra 1938, men Achmatova vovede ikke at skrive dem ned før en gang i 60'erne. Inden de blev trykt i 1987, fandtes de i 11 kopier i Sovjet, hos folk der havde lovet hende at holde dem hemmeligt. Da det blev muligt at udgive dem, udspillede der sig et veritabelt slagsmål om rettighederne mellem to af de toneangivende litterære tidsskrifter Znamia og Novyj mir. Resultatet blev, at den udkom begge steder omtrent samtidigt. (Achmatova døde i 1966. Hun debuterede allerede før revolutionen og tilhørte den såkaldte akmeistiske skole inden 
for poesien. Hun var gift med poeten Nikolaj Gumiljov, der efter revolutionen blev skudt af bolsjevikkerne, mistankt for kontrarevolutionær virksomhed. Han er en af dem, der er blevet rehabiliteret under perestrojkaen.) "Efter Requiem er det umuligt at skrive sådan, som vi har gjort det tidligere«, sagde en forfatter (Oleg Poptsov) til mig for et par år siden. "Fra nu af vil litterær kvalitet blive målt med dette vark som målestok «.

Omtrent samtidig med Requiem udkom en roman der i modsxtning til Achmatovas digtcyklus ikke handlede om dem, der gik til grunde under Stalin, men om de mennesker der kom ud af stalintiden. Det drejer sig om Aleksander Beks Den ny udnovnelse (1973, dansk 1987). Romanen, der havde ligget næsten 20 år $\mathrm{i}$ censurens arkiver, inden den udkom, er en psykologisk analyse af bureaukratmentaliteten, og den beskriver de mekanismer, der skabte stalintidens samfundsstøtter og systemtilhængere. Også den vakte stor opmærksomhed og tog hul på en række officielle myter. Det helt store værk om stalintiden, som nok har haft st $\emptyset$ rst betydning for den debat om Stalin, der er opstået og er blevet intensiveret inden for de sidste par år, er Vasilij Grossmans monumentale krønike om slaget ved Stalingrad Liv og skabne. Den var fardigskrevet i 1960, men udkom først i 1987. Manuskriptet blev udsmuglet til Vesten i 70'erne og udgivet i en række lande blandt andet Danmark (i 1985).

Også i Liv og skabne er temact mennesket og historien, enkeltindividets skæbne og systemets håndhævelse af den »historiske nødvendighed«. Grossman parallelliserer stalinismen og fascismen. Begge systemer er totalitære og inhumane, er dens konklusion. Grossmans roman vakte opsigt ikke bare for den tydelige sammenligning mellem stalintidens Sovjet og Hitlertyskland. Som en af de første slog Grossman en pæl gennem den udbredte myte om Stalin som den store militærstrateg. Slaget ved Stalingrad, og dermed sejren over nazisterne, blev, hævder Grossman, vundet på trods af og ikke takket være Stalin og particts ledelse. Han døde i 1964, og noget af det sidste, han nåede at opleve, var, at Suslov, den daværende chefideolog, gjorde ham klart, at hans roman var ideologisk skadelig og næppe ville blive udgivet de første 200 år.

Bag mange af de »nye«, gamle værker ligger grundige undersøgelser og »feltstudier «. Forfatterne har ofte, som f.eks. Grossman, der under krigen var krigskorrespondent, været øjenvidne til begivenheder, de skildrer. De har samlet materiale og bygget arkiver op, de har taget interviews og lagt puslespil med de fragmentariske bidder af sandheden, som trods alt er sivet ud fra de officiclle kilder. Det drejer sig således om værker, der i mange tilfælde har en høj historisk sandhedsværdi. For et par år siden blev det besluttet at indstille eksaminationerne $\mathrm{i}$ historie $\mathrm{i}$ 
alle sovjetiske skoler, fordi det pensum, der blev brugt, blev erklæret for udueligt. Indtil det kunne fremskaffes nyt undervisningsmateriale skulle man, blev der foreslået, bruge skønlitterære værker.

Der er udkommet romaner, som giver nye informationer om kollektiviseringen, f.eks. 2. del af Boris Mozjaevs Bønder og bønderkoner (1987), og om revolutionen og borgerkrigen, hvor hovedværket naturligvis er Boris Pasternaks forkætrede og Nobel-prisbelønnede Doktor Zjivago (1955), der efter mange års tovtrækkeri endelig udkom i 1987. Der er udkommet værker fra tiden før revolutionen, som præsenterer tanker og idćcr, der efter 1917 ikke mere var »til gavn for menneskeheden «, fordi de pegede bagud og ikke fremad f.eks. værker af filosofferne Vladimir Solovjev og Nikolaj Berdjaev; historikeren Nikolaj Karamzins Ruslandshistorie fra begyndelsen af det 19. århundrede kører i øjeblikket som føljeton i et af de centrale litterære tidsskrifter. (Den er i 12 bind!)

I 50'erne og 60'erne havde forfatterne blikket rettet fremad. En ung generation med Jevgenij Jevtusjenko, Andrej Voznesenskij, Vasilij Aksjonov og Bulat Okudzjava i spidsen forkastede fortiden, men skrev digte og romaner der var gennemsyret af en tro på fremtiden. Alene titlen på en af periodens mest berømte værker, Aksjonovs ungdomsoprørske roman Stjernebilletten (1961, dansk 1962), antyder en optimistisk holdning. Det første opgør var primært et opgør med "personkulten « og de misgerninger der blev begået i stalintiden. Kritikken blev standset der, hvor den kom for tæt på Stalin - og dermed på dem, der forvaltede hans arv. Opgøret nåede aldrig ud over en kritik af »afvigelser « fra noget, ingen (åbent) tog afstand fra - det socialistiske system og den marxistisk-leninistiske ideologi. I dag reviderer man ikke bare en del af det forgangne, men hele den epoke man har gennemlevet siden revolutionen. Til forskel fra det første tøbrud er også det politiske system taget op til revision. Mange af de nu frigivne varker fra Brezjnev-tiden ligger som allerede nævnt $i$ forlangelse af 50'ernes og 60'ernes afbrudte opgør med stalintiden. Men selv om kritikken af fortiden går dybere end under det første opgør, er der tale om systemloyale positioner. Dudintsev, Rybakov og Granin (andre kunne nævnes) er anti-stalinister, men ikke anti-leninister. De cr systemets mænd og Gorbatjovs sikreste støtter. Litteraturkritikeren Alla Latynina kalder dem for det nye establishment.

Med udgivelsen af en række ældre værker af f.eks Michail Bulgakov, Andrej Platonov, Anna Achmatova og Boris Pasternak samt verker af forfattere, der hører hjemme i en anden tradition end Rybakov-Granin gruppen, er analysen af, hvorfor det gik så galt, gåct endnu mere i dybden - og langere tilbage i historien. Det drejer sig om varker af forfattere 
som f.eks. Vladimir Tendrjakov, Vladimir Solouchin og ovennavnte Boris Mozjaev, der allesammen mere eller mindre hørte hjemme i den såkaldte landsbylitteratur i 60'erne og 70'erne, og som videreførte oprørstraditionen på en anden måde og med andre virkemidler end 50'er-generationen. Disse forfattere standser ikke ved stalintiden og personkulten. De viser $\mathrm{i}$ deres værker, at ondets rod skal søges længere tilbage i historien.

Om kort tid udkommer endnu et værk af Vasilij Grossman, det tidligere omtalte Alt flyder. Grossman, der hører med til den første tøbrudsgeneration, men er betydelig mere radikal end de fleste, slår her uden omsvøb en pæl igennem den udbredte myte om, at Stalin var roden til alt ondt, og i konsekvens heraf at han var et produkt - af sig selv. Alt flyder er fortalt i tredje person af en forhenværende lejrfange, men laseren er ikke i tvivl om, at det er Grossman selv, der her i slet skjult form formulerer sit generalopgør med Lenin. Stalin forvrængede ikke Lenins ideer, hævder han. Stalin fuldkommengjorde Lenins model og førte den ud i sin yderste og logiske konsekvens. Lenin på sin side var et produkt af den autoritære russiske tradition. Hvis Alt flyder virkelig udkommer, er der grund til at tro, at også Aleksander Solzjenitsyns omstridte dokumentariske roman Gulag Øhavet, der længe har ståct på det litterære tidsskrift Novyj mirs program, omsider vil blive offentliggjort.

Medens 50 'ernes tøbrud rettede blikket fremad og udad, er 80'ernes tøbrud i høj grad orienteret bagud og indad. 50’ernes internationale orientering, med udgivelser af vestlige værker, forfatterdelegationer på charmeoffensiv i vesten og en ung generation, der lod sig inspirere af den borgerlige »dekadente « fortrinsvis amerikanske kultur, er i dag afløst af cn søgen cfter egne rødder, den »fortrængte« nationale identitet, den bortrctoucherede historiske sandhed og »glemte« åndelige tradition. Det er i klar forlængelse af 70 'ernes fokusering på moderniserings- og sovjetiserings-processens effekter og på mange måder i paradoksal modsætning til, hvad vi oplever på den politiske arena. Her er det netop internationalisering og større åbenhed over for det internationale samfund, der gør sig gældende. Men måske er det ikke så paradoksalt endda. Det politiske sprog er det dagsaktuelle og situationens sprog. Kunst og kultur har en anden semantik. Orienteringen indad og bagud er tilsyneladende nødvendig for at finde frem til en sandhed, uden hvilken der ikke kan skabes en litteratur, der er et genuint udtryk for sin tid. Den "gamle« litteratur er en del af den sandhed, man søger. Derfor er det netop denne litteratur, der er det mest adækvate udtryk for den periode sovjetsamfundet nu er inde $i$. 